Original article

Received: 28 March 2017 / Accepted: 2 August 2017

\title{
MULTI-CRITERIA ANALYSIS FOR SOLAR FARM LOCATION SUITABILITY
}

\author{
Michal Mierzwiak, Beata Calka \\ Institute of Geodesy, \\ Faculty of Civil Engineering and Geodesy, \\ Military University of Technology, Warsaw, Poland
}

\begin{abstract}
Currently the number of solar farms, as a type of renewable sources of energy, is growing rapidly. Photovoltaic power stations have many advantages, which is an incentive for their building and development. Solar energy is readily available and inexhaustible, and its production is environmentally friendly. In the present study multiple environmental and economic criteria were taken into account to select a potential photovoltaic farm location, with particular emphasis on: protected areas, land cover, solar radiation, slope angle, proximity to roads, built-up areas, and power lines. Advanced data analysis were used because of the multiplicity of criteria and their diverse influence on the choice of a potential location. They included the spatial analysis, the Weighted Linear Combination Technique (WLC), and the Analytic Hierarchy Process (AHP) as a decisionmaking method.

The analysis was divided into two stages. In the first one, the areas where the location of solar farms was not possible were excluded. In the second one, the best locations meeting all environmental and economic criteria were selected. The research was conducted for the Legionowo District, using data from national surveying and mapping resources such as: BDOT10k (Database of Topographic Objects), NMT (Numerical Terrain Model), and lands and buildings register. Finally, several areas meeting the criteria were chosen. The research deals with solar farms with up to $40 \mathrm{~kW}$ power.

The results of the study are presented as thematic maps. The advantage of the method is its versatility. It can be used not only for any area, but with little modification of the criteria, it can also be applied to choose a location for wind farms.
\end{abstract}

Keywords: solar farms, Multi-Criteria Decision Analysis, spatial analysis 


\section{Introduction}

The directive of the European Parliament and of the Council 2009/28/EC of 23 April 2009 on the promotion of the use of energy from renewable sources makes clean energy one of the main objectives of the European Union until 2020 and later, up to 2030. Poland, like other Member States, is obliged to reduce the production of electricity from conventional sources and to make use of renewable ones. By 2020 $15 \%$ of energy is going to be produced from renewable energy sources.

The Masovian Voivodship constitutes one of the highest shares of the country's energy consumption, with a similar situation in its intensively growing urban centres. The Legionowo District, and, in particular, the town of Legionowo, is characterized by a rapid rise in the number of inhabitants, this way increasing the demand for energy, especially electricity. In many parts of Poland, in particular in the north and northeast, power grid is underdeveloped, which may result in problems with the delivery of electricity to consumers in the future (Paska \& Surma, 2014). According to the guidelines of the European Parliament and Council Directive 2010/75/EU of 24 November 2010 on industrial emissions (integrated pollution prevention and control), it is necessary to limit the production of energy from fossil fuels and the resulting emissions of $\mathrm{CO}_{2}$ and other harmful substances into the atmosphere. In Poland those who invest in green energy are eligible for assistance to implement the project, provided by the state and other institutions, according to the regulation of the Minister of Energy of 1 December 2016 on calculation of the amount of state aid for producers of electricity from a renewable energy source, generated in a renewable energy installation. Therefore, to ensure adequate amounts of energy it is necessary to promote the use of renewable energy sources, especially those directly providing electricity, like photovoltaic panels.

Fast and dynamic development of modern technologies to produce solar panels makes them more efficient, generating more energy output, so the investment in this source of energy is becoming more profitable. Those panels are environmentally friendly, being one of clean energy sources (Serrano-Luján, 2017). An additional advantage is the fact that in accordance with the Act of 7 July 1994 on the construction law, building permission is not required for solar panels (photovoltaic farms) if their power does not exceed $40 \mathrm{~kW}$. However, according to Article 59 of the Act of 27 March 2003 on the planning and spatial development any change in land use in the form of the construction of a building object or any other construction work or change in the way in which the building object or its part is used requires an adequate decision. The present study does not take into account planning requirements.

Renewable energy is particularly important for the Legionowo District because of very high air pollution, especially in autumn and winter, with a frequent occurrence of smog. Investments in this type of renewable energy sources are a strong incentive for the area. The aim of this paper is to elaborate methodology for selection of the best locations for solar farms, using multi-criteria analysis, GIS tools, and spatial data collected by the geodetic and cartographic centres. The novelty of the method bases on the combining Boolean, AHP (Analytical Hierarchy Process) and WLC (Weighted Linear Combination) methods and top-down approach. The experimental delimitation of areas suitable for solar farm location was done for Legionowo District, located in the vicinity of Warsaw. The advantage of the method is its versatility. It can be used not only for any area, but with little modification of the criteria, it can also be applied to choose a location for wind farms. 


\section{Methods}

Application of multi-criteria data analysis can be useful in a decision-making process in many different areas of human activity. It is a collection of mathematical methods and tools that allows comparing different variants of decision-making, using various, even contradictory, criteria (Hejmanowska \& Hnat, 2009; Janke, 2010). The aim of the multi-criteria analysis is to work out the most favourable solution. The process of resolving multi-criteria issues is defined in literature as MCDA (Multi Criteria Decision Analysis) or MCDM (Multi Criteria Decision Making). For many years multi-criteria analyses have been used together with GIS (Hott et al., 2012; Tahri, 2015; Janke, 2010). A broad review of growing literature on this mature presents Malczewski (2006).

Selection hard or soft criteria, used in the process, is the first step in multi-criteria analysis (Pokonieczny, 2016). Hard criteria, which are also named as Boolean, allows to delimit sites that meet or do not meet them, while soft criteria make it possible to show suitability level for a particular purpose. The result of the analysis based on hard criteria is unambiguous; the criterion disqualifies or qualifies the site (Tomala et al., 2016). It is different in the case of soft criteria, where the difference between a suitable and unsuitable area is specified by a function. Of course, the appropriate selection of criteria for the analysis is crucial (Bober et al., 2016).

Literature shows clearly that environmental criteria, including solar radiation and aspect, have a very large impact on the selection of areas for the location of a solar farm (Merrouni, 2013; Mc Kinney, 2014). In addition, in many analyses criteria like proximity to built-up areas, proximity to power lines, or proximity to roads are taken into consideration (Hott, 2012; Effat, 2013). These criteria have an impact on minimising solar farm construction costs generated by the provision of appropriate technical infrastructure. The criteria that determine the location of solar farms can be classified into three groups: environmental, technical, and socio-economic.

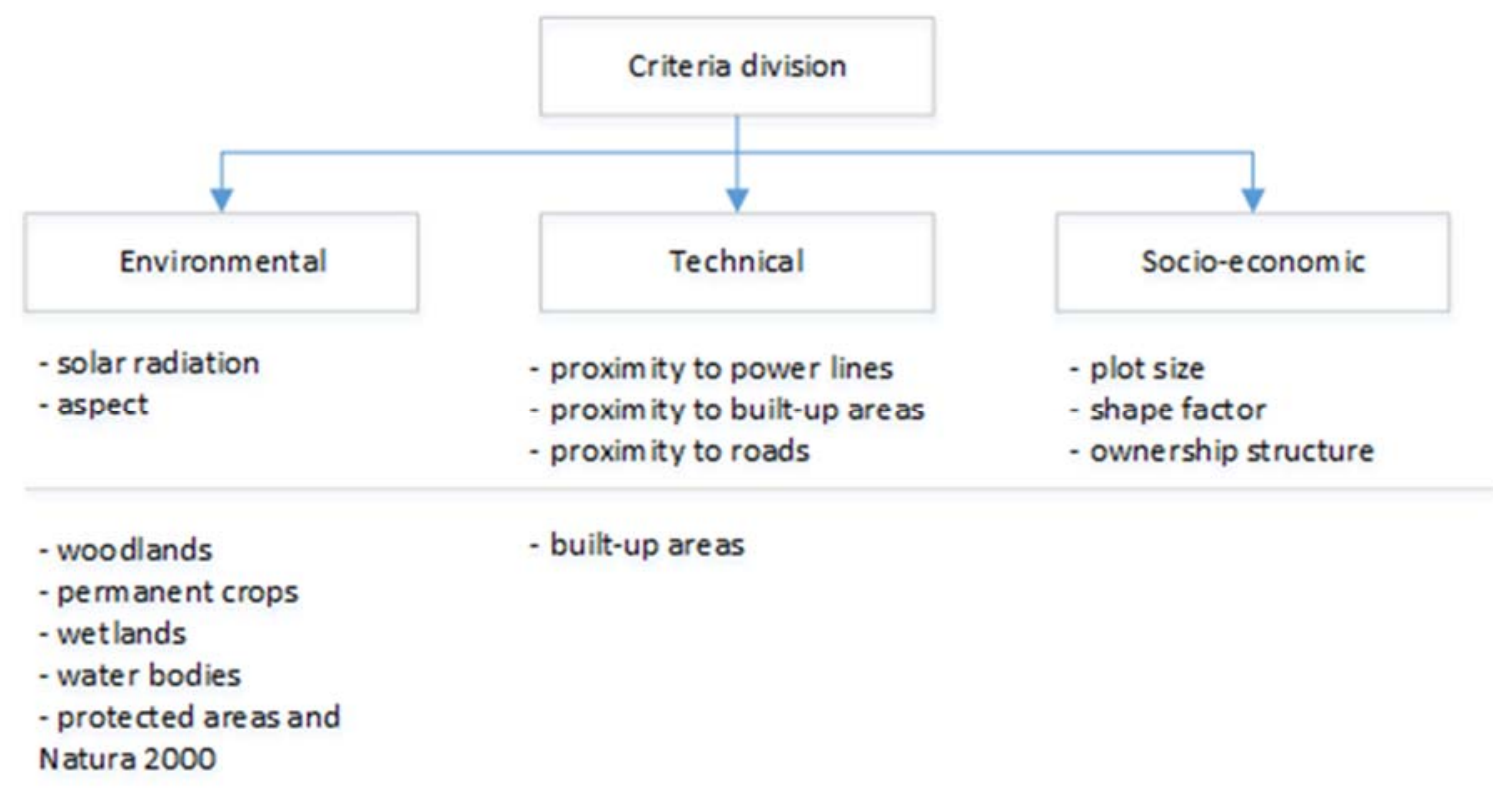

Fig. 1. Typology of solar farm location criteria

We assumed that the delimitation of the area suitable for solar farm is based on two-stage model. The first stage excluded area where location of a solar farm is impossible due to land use (woodland areas and permanent crops, water bodies and 
wetlands, and built-up areas) and high nature of environment (protected area and Natura 2000), which were perceived as hard criteria. This was done with Boolean method (Hejmanowska \& Hnat, 2009). In the second stage remaining lands are validated according to the criteria presented in Fig. 1 . The validation was based on the weighting criteria using AHP and WLC methods (Hejmanowska \& Hnat, 2009). As the results each land polygon is assigning to suitability rank: low, medium and high presenting potential for solar farm location. The workflow is shown in Fig. 2.

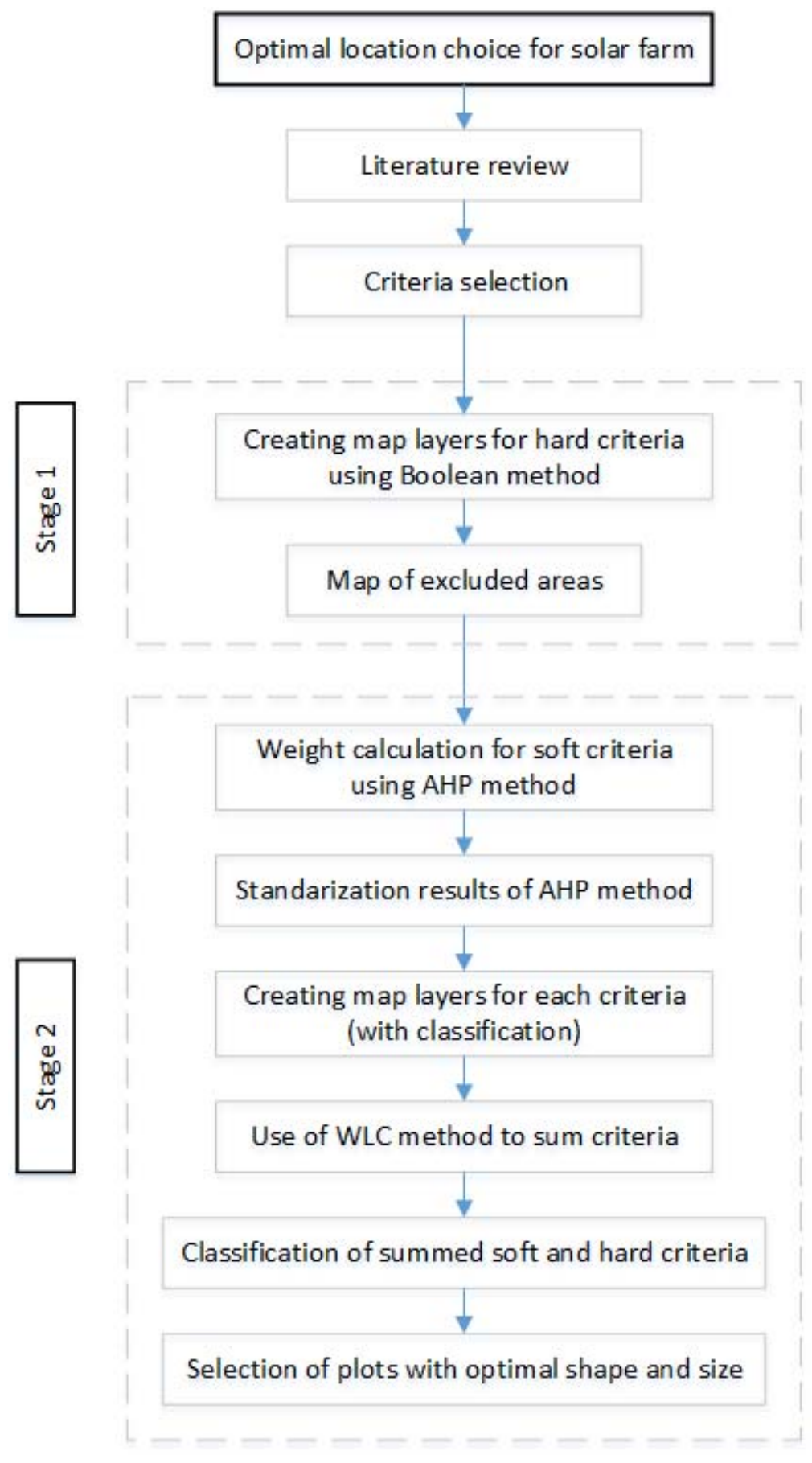

Fig. 2. Flow chart 
The second stage involves determination of weights of soft criteria, going through Analytical Hierarchy Process (AHP) (Saaty, 1987), standardization of the results, and the development of classified maps of the suitability of areas to locate a farm. It is not necessary to make complex choices because the AHP method allows comparing single criteria or pairs of variants (Asakereh, 2014). The analysis consists of two steps. The first one is a creation of a hierarchical structure and evaluation of the criteria within the framework of this structure. The second step of the AHP analysis is to assign weights to the criteria, to show what their impact on the reached goal is. Evaluation of the criteria is made by comparing them in pairs. The weights are chosen using a nine-point Saaty's scale (Saaty, 1987).

The value of the criteria for solar farm selection sites (Table 1) are defined after broad study of literature and legal European and Polish acts. Each criterium can take one of tree values ( 1 - for the areas with low potential, 2 - for the areas with medium potential and 3 - for the areas with high potential).

Table 1. Pair wise comparison matrix of the main criteria with respect to the goal

\begin{tabular}{|c|c|c|c|c|}
\hline \multicolumn{5}{|c|}{ Ranges of criteria } \\
\hline NO. & Criterion & & Range & Units \\
\hline \multirow{3}{*}{1.} & \multirow{3}{*}{ Aspect } & 1. & $\mathrm{~N}, \mathrm{NE}, \mathrm{NW}$ & \\
\hline & & 2. & $E, W$ & \\
\hline & & 3. & S, SE, SW, flat area & \\
\hline \multirow{4}{*}{2.} & \multirow{4}{*}{ Solar radiation } & & & \\
\hline & & 1. & $455130,5-606652$ & \multirow{3}{*}[\mathrm{W}^{*}\mathrm{m}^{-2}]{} \\
\hline & & 2. & $606652,1-891040$ & \\
\hline & & 3. & $891040,1-1042561,4$ & \\
\hline & & & & \\
\hline \multirow{3}{*}{3.} & \multirow{3}{*}{$\begin{array}{c}\text { Proximity to built-up } \\
\text { areas }\end{array}$} & 1. & $0-500$ & \multirow{3}{*}[\mathrm{m}]{} \\
\hline & & 2. & $500-3000$ & \\
\hline & & 3. & $>3000$ & \\
\hline & & & & \\
\hline \multirow{3}{*}{4.} & \multirow{3}{*}{$\begin{array}{l}\text { Proximity to power } \\
\text { lines (medium- } \\
\text { voltage) }\end{array}$} & 1. & $>1500$ & \multirow{3}{*}[\mathrm{m}]{} \\
\hline & & 2. & $500-1500$ & \\
\hline & & 3. & $0-500$ & \\
\hline & \multirow{4}{*}{ Proximity to roads } & & & \multirow{4}{*}[\mathrm{m}]{} \\
\hline \multirow{3}{*}{5.} & & 1. & Over 1500 & \\
\hline & & 2. & $500-1500$ & \\
\hline & & 3. & $0-500$ & \\
\hline
\end{tabular}

Cartographic presentation showing several criteria with different weights is possible owing to the WLC methods (Weighted Linear Combination). It is one of the most widely used Multi-Criteria Evaluation (MCE) methods for land suitability analysis. It involves standardization of suitability maps, assigning the weights of relative importance to the maps, and then combining the weights and standardized suitability maps to obtain an overall suitability score (Malczewski, 2004). Combination of the WLC method and a thematic layer of excluded areas makes possible to obtain a map rating the areas in terms of their usefulness for solar farm location. The last stage involved selecting areas for farm location, the best with regard to socioeconomic conditions, such as the size of a location or its shape. The shape and size 
of the area, as some studies show, is extremely important for many investment purposes (Maleta \& Calka, 2015; Gąsiorowski \& Bielecka, 2014). In this study we assumed that the optimal farm size for investor is 2 ha. The results of the analysis are presented in the form of thematic maps according to the rules given by Medyńska-Gulij (2014) and Lorek (2016).

\section{Characteristics of the Legionowo District}

The Legionowo District is located in the central part of Mazovian Voivodship. It consists of five communes with a total area of $390 \mathrm{~km}^{2}$, inhabited by 113242 people. The average population density is about 290 inhabitants per sq $\mathrm{km}$. The main centre of the region is the town of Legionowo located in the southern part of the District. Localisation map of the Legionowo District is shown in Fig 3.

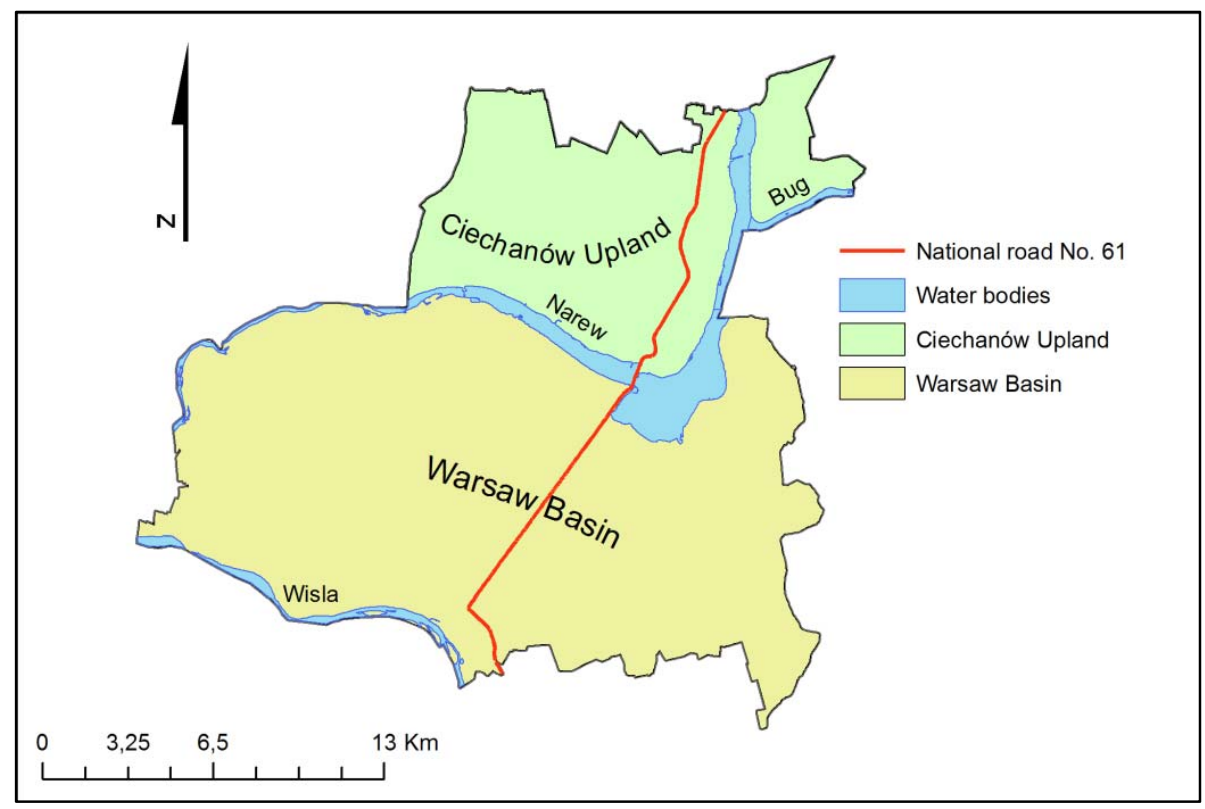

Fig. 3. Localisation map of the Legionowo District

The District is located in the Mazovian Lowland, with flat or undulating moraine, slightly declining (locally up to $12^{\circ}$ ), the Ciechanów Upland, and the Warsaw Basin. The southern and central part of the District, located in the Warsaw Basin, is mainly covered with Pleistocene age terrace deposits forming plains, with numerous hills and sandy hills. The soil of the Legionowo District is formed from Quaternary deposits. In the northern part of the Ciechanów Upland the earth material is boulder clay, gravel, and sand, while areas of river valleys are covered with sediment sand of glacio-fluvial and fluvial origin. The Vistula, Bug, and Narew rivers flow across the District. There is a growing demand for electricity because of an intensive development of the District, with a constantly growing number of residents, because of the proximity of Warsaw and the presence of major routes, like national road No. 61 from Warsaw to Augustów. One of the ways to ensure energy security in the region is the investment in renewable energy, in particular in solar energy (Strzelecki, 2011, Ostaszewska \& Richling, 2009).

In process of selection of suitable local farm location, different spatial data were used (Brzezinska-Klusek, 2013). The main source of spatial data for the study was BDOT10k (Database of Topographic Objects), provided by the Central Geodetic and 
Cartographic Documentation Centre. BDOT10k is a country wide topographic data with the level of detail and thematic scope corresponding to the civilian maps at a 1:10000 scale (Bielecka, 2015; Calka et al., 2016). The geometric accuracy of object size estimated by Ławniczak and Kubiak (2016) is about $2 \%$ different than field measurement. The following layers were used for the analysis: roads, built-up areas, power lines, protected areas, forest, permanent crops, wetlands and water bodies. Value ranges of selected buffers are shown in Tab.1. Layers selected from BDOT10k data were used to prepare Fig. 4.

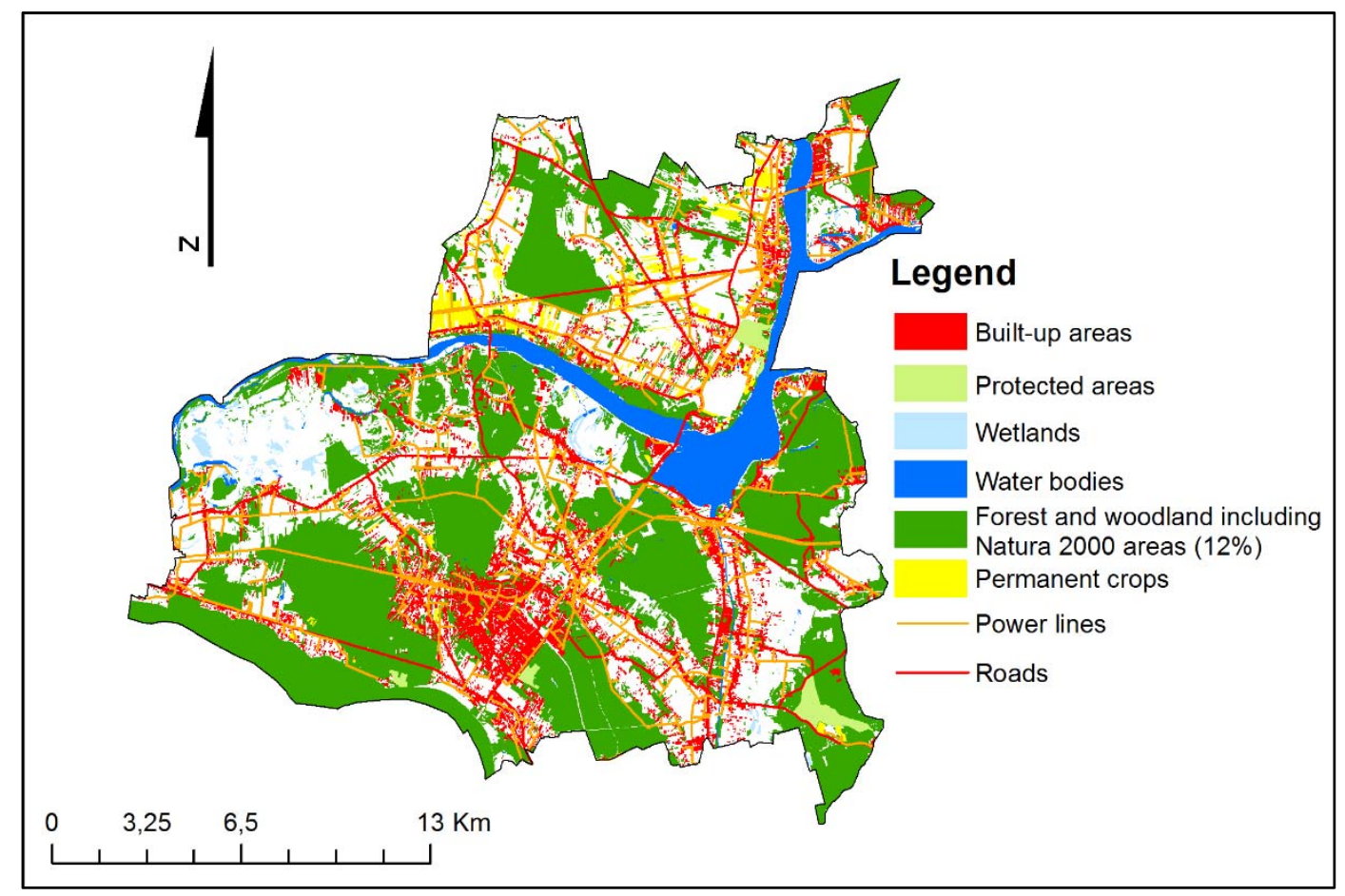

Fig. 4. Areas excluded from analysis

Additionally, in order to find information about slopes and aspect, SRTM (Shuttle Radar Topography Mission) data were used. SRTM DEM 1 provides a set of points covering the model of terrain with cells of $1^{\circ} \times 1^{\circ}$, produced with the C-band interferometric technique. The spatial reference system used for the SRTM data is WGS84 System.

In the final stage of the analysis, it was important to take into account data on parcels in the district obtained from the land and building register. Those data could have been used to finally select land suitable for a solar farm. An adequate application for an access to the data was filed to the District Office in Legionowo but after a long delay it was turned down.

\section{Results}

Almost $60 \%$ of the district area was excluded from further analysis using hard criteria and Boolean method. The results of this procedure are presented in Fig. 5. The map shows areas completely unsuitable for solar farm location.

The excluded locations were situated, among others, in built-up areas, protected areas (Natura 2000, nature reserves), water bodies, wetlands, and woodlands areas. Forests and woodlands constitue more than $65 \%$ of the excluded areas, $17 \%$ is builtup areas, and $10 \%$ is covered with water bodies (Fig. 6). 


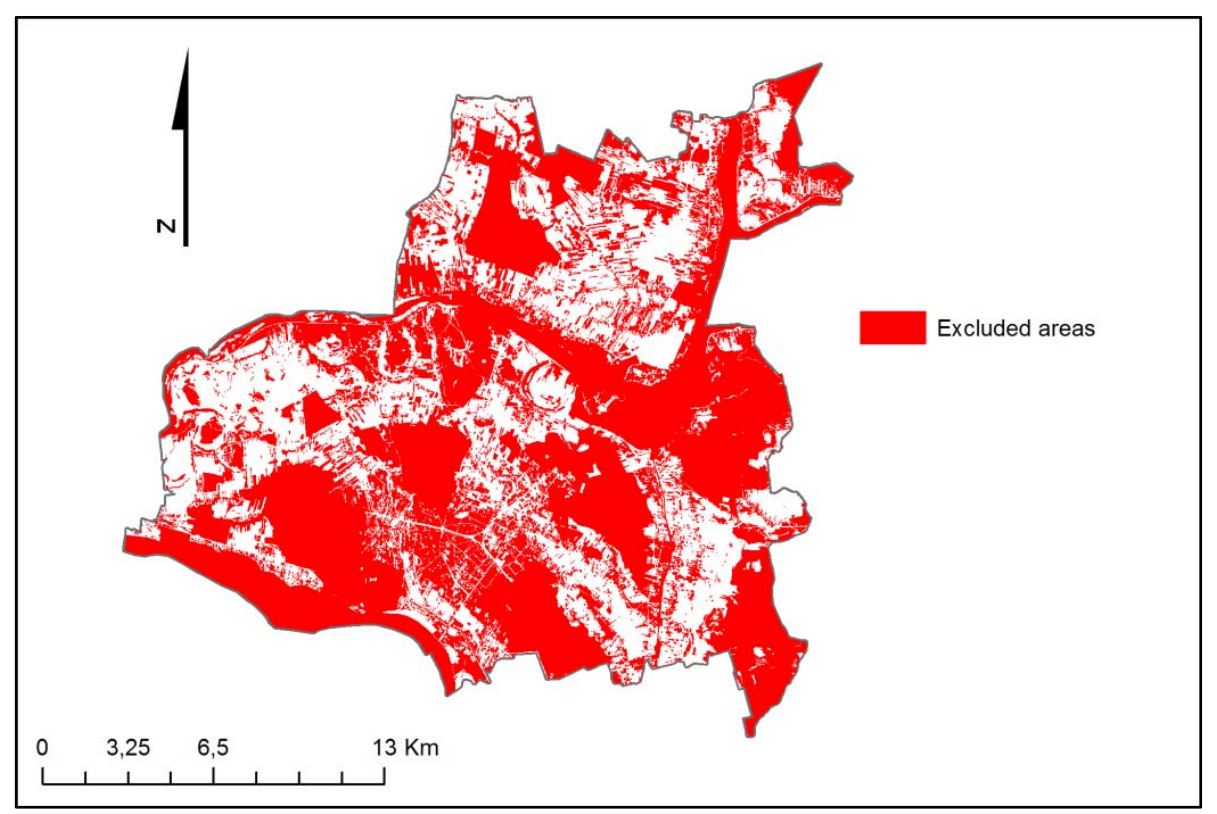

Fig. 5. Areas excluded from analysis
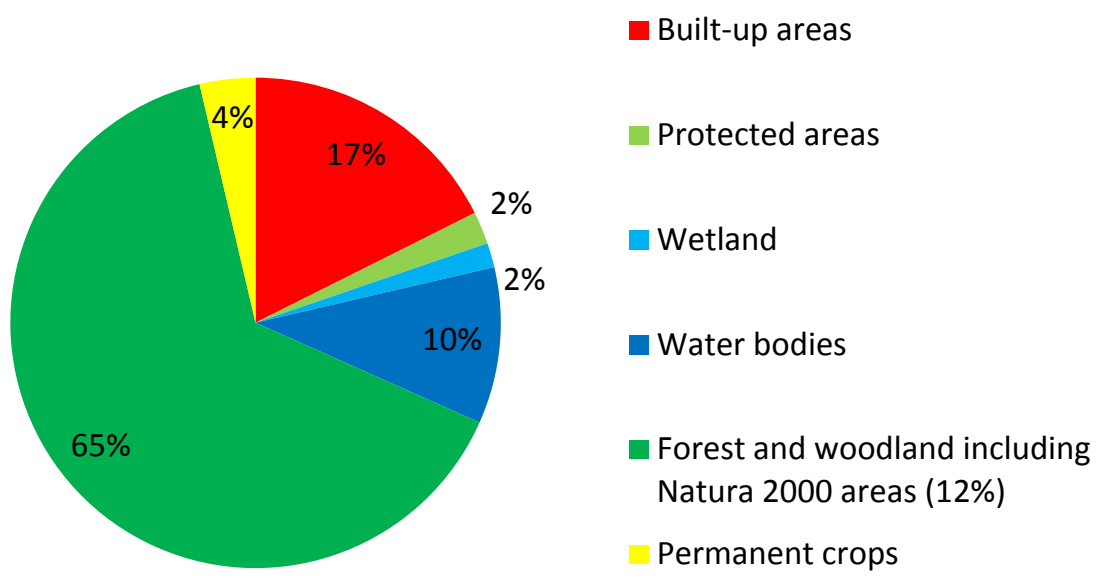

Fig. 6. Percentage of excluded areas

Analysis of land suitability for solar farm location was based on the environmental criteria (solar radiation, aspect) and three technical criteria (proximity to roads, builtup areas and power lines). The easiest way to determine the weights is pairwise comparison matrix shown in Table 2, while matrix of obtained criteria weights is presented in Table 3. This analysis was conducted with the use of AHP method.

The results show that aspect, has the greatest influence on solar farm location, with a weight equal to $41 \%$, while solar radiation has the weight of $38 \%$. Relief of the tested area is very diversified, which causes significant differences in the suitability of sites. The best locations are in the northern part of the District, as it has an orientation towards the south and a slope towards the River Narew. The results of the present experiment, in which aspect and solar radiation weights are high and similar in value, have been confirmed in literature (Effat, 2013; Merrouni, 2013).

Legionowo District areas were classified into three groups with high, medium, and low potential to locate a solar farm with use of equal interval classification method (Fig. 7). 
Table 2. Pairwise comparison matrix of the main criteria with respect to the goal

\begin{tabular}{|l|c|c|c|c|c|}
\hline & $\begin{array}{c}\text { Solar } \\
\text { radiation }\end{array}$ & Aspect & $\begin{array}{c}\text { Proximity to } \\
\text { built-up } \\
\text { areas }\end{array}$ & $\begin{array}{c}\text { Proximity to } \\
\text { power lines }\end{array}$ & $\begin{array}{c}\text { Proximity to } \\
\text { roads }\end{array}$ \\
\hline Solar radiation & 1 & 1 & 5 & 7 & 9 \\
\hline Aspect & 1 & 1 & 7 & 7 & 9 \\
\hline $\begin{array}{l}\text { Proximity to } \\
\text { built-up areas }\end{array}$ & 0.2 & 0.14 & 1 & 3 & 5 \\
\hline $\begin{array}{l}\text { Proximity to } \\
\text { power lines }\end{array}$ & 0.14 & 0.14 & 0.33 & 1 & 5 \\
\hline $\begin{array}{l}\text { Proximity to } \\
\text { roads }\end{array}$ & 0.11 & 0.11 & 0.20 & 0.20 & 1 \\
\hline TOTAL & 2.45 & 2.40 & 13.53 & 18.20 & 29.00 \\
\hline
\end{tabular}

Table 3. Matrix of obtained criteria weights (Normalized Pairwise Comparison Matrix)

\begin{tabular}{|l|c|c|c|c|c|c|}
\hline & $\begin{array}{c}\text { Solar } \\
\text { radiation }\end{array}$ & Aspect & $\begin{array}{c}\text { Proximity } \\
\text { to built-up } \\
\text { areas }\end{array}$ & $\begin{array}{c}\text { Proximity } \\
\text { to power } \\
\text { lines }\end{array}$ & $\begin{array}{c}\text { Proximity } \\
\text { to roads }\end{array}$ & $\begin{array}{c}\text { WEIGHT } \\
\%\end{array}$ \\
\hline Solar radiation & 0.408 & 0.417 & 0.369 & 0.385 & 0.310 & 38 \\
\hline Aspect & 0.408 & 0.417 & 0.517 & 0.385 & 0.310 & 41 \\
\hline $\begin{array}{l}\text { Proximity to } \\
\text { built-up areas }\end{array}$ & 0.082 & 0.060 & 0.074 & 0.165 & 0.172 & 11 \\
\hline $\begin{array}{l}\text { Proximity to } \\
\text { power lines }\end{array}$ & 0.058 & 0.060 & 0.025 & 0.055 & 0.172 & 7 \\
\hline $\begin{array}{l}\text { Proximity to } \\
\text { roads }\end{array}$ & 0.045 & 0.046 & 0.015 & 0.011 & 0.034 & 3 \\
\hline TOTAL & 1.00 & 1.00 & 1.00 & 1.00 & 1.00 & 100 \\
\hline
\end{tabular}

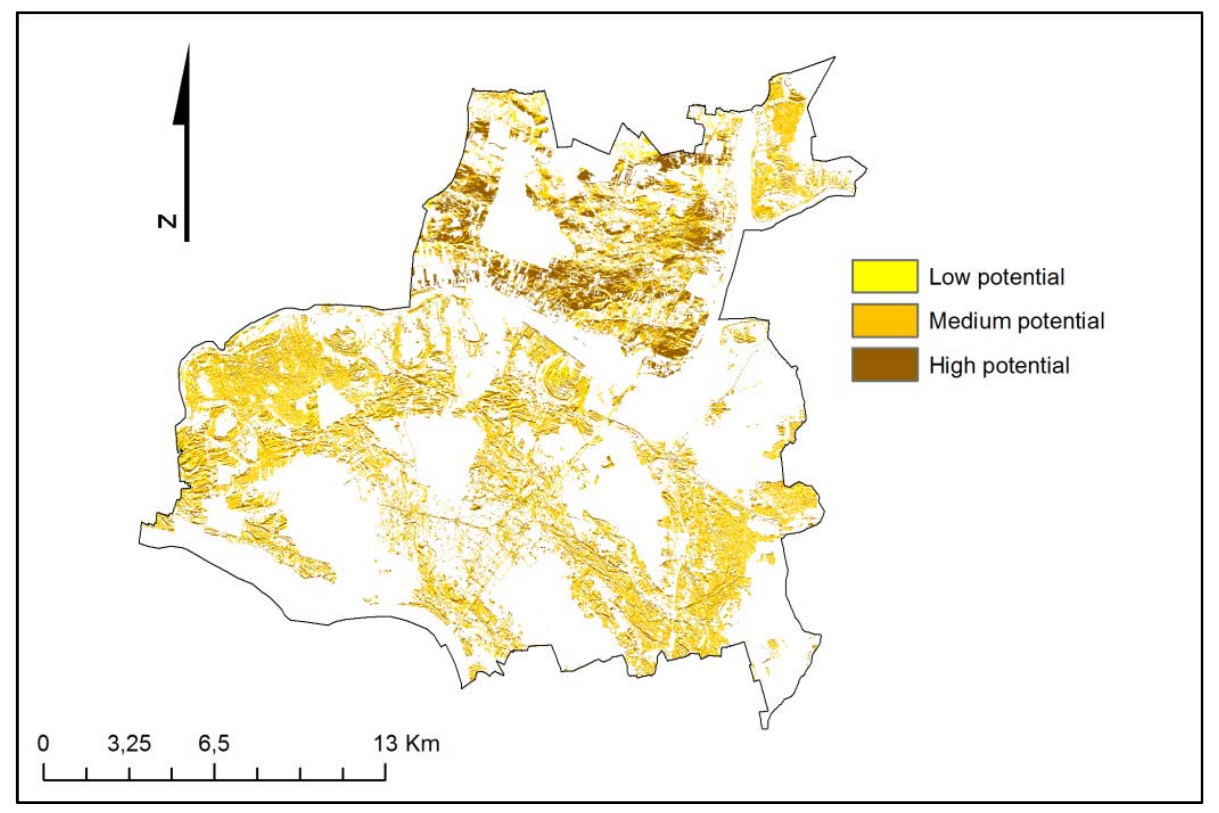

Fig. 7. Typology of solar farm location criteria 
Areas with medium potential (23\% of the area of the district) constitute the largest part, while the areas with low potential represent the smallest share (5\%) (Fig. 8). For further analysis only the sites with high potential $(12 \%)$ were selected.

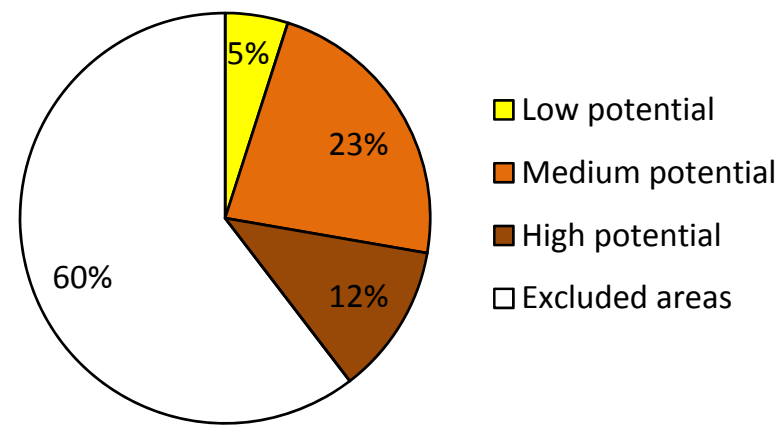

Fig. 8. Suitability of solar farm location

In order to select the best location for a solar farm, the size of the polygons and its regular shape are the most important. The land should not be fragmented into too many parcels because with fewer owners its purchase is easier. For each area a shape factor was determined and area with optimal shape and the required size of 2 ha were selected. The analysis resulted in a group of 47 locations meeting all required criteria. Excessively fragmented sites, or ones with an elongated shape, were excluded. About $25 \%$ of suitable areas had high potential as a location, covering about $3 \%$ of the total area of the Legionowo District. The selected sites are presented in Fig. 9. All of them are located in the northern part of the District, in the Ciechanów Upland. They meet the criteria used in the AHP analysis, most important of which are the solar radiation and aspect. The Upland is more elevated above sea level than the rest of the District, and it slopes towards the south, south east and south west, making it the most optimal due to the best environmental conditions.

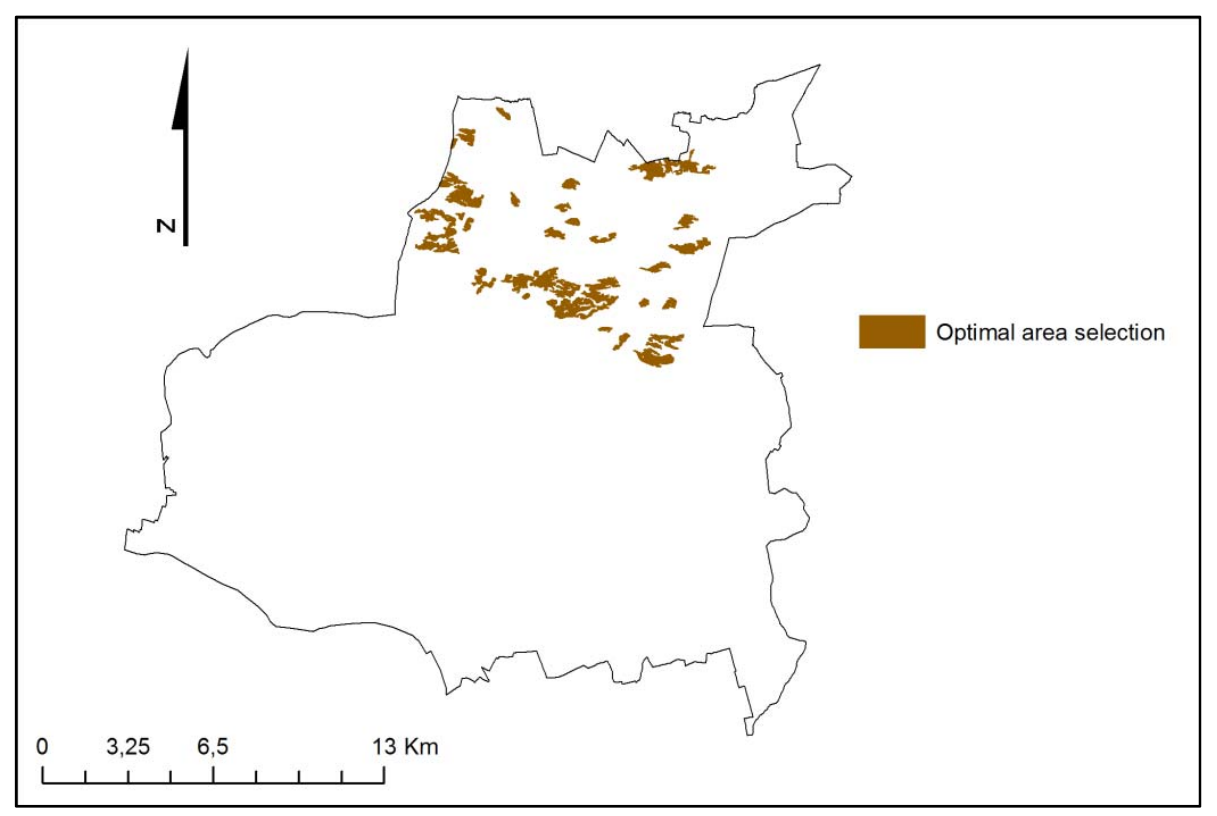

Fig. 9. Typology of solar farm location criteria 


\section{Conclusions}

Rising electricity production from non-renewable energy sources leads to a gradual depletion of natural resources, and has a negative effect on the environment. That is why national and local legislation promotes a wider use of renewable energy sources, including photovoltaic ones. Because of the existing land use, or environmental and economic conditions, solar farms can be only located in certain areas. The aim of the article is to present a methodology for the selection of the best areas for solar farms and experimental delimitations such places in the District of Legionowo. The article shows that the application of the Multi-Criteria Decision Analysis and Geographic Information System is a very effective combination to deal with the matter.

An important step of the study was to define location criteria. Analyses of adequate literature on photovoltaic farms enabled the authors to select such criteria as environmental (solar radiation, aspect), technical (proximity to roads, electrical power lines, and buildings), and economic (the size and shape of the area). Some criteria for the location of the solar farm are not particularly important and do not affect the suitability of the site much. Therefore, the AHP method was used to determine the weight of all the criteria. The downside of the method was some subjectivity in assessing validity of pairs of criteria, which would have affected the final weight. However, an exhaustive analysis and discussion of the results enabled the authors to determine optimal weights.

All the areas with the best conditions are located in the north of the Legionowo District. The choice is mainly determined by the fact that the land there has the best insolation, with its orientation towards the south, which resulted in the highest weights in the study. Although almost $60 \%$ of the area was excluded from the analysis, there were still places with good location conditions for solar farms.

\section{Acknowledgements}

The authors would sincerely like to extend their gratitude to Professor Elzbieta Bielecka for support and guidance.

The study was conducted within research No RMN/803/2016, at the Military University of Technology, Faculty of Civil Engineering and Geodesy, Institute of Geodesy and Cartography.

\section{References}

Asakereh A., Omid M., Alimardani R., \& Sarmadian F. (2014). Developing a GISbased Fuzzy AHP Model for Selecting Solar Energy Sites in Shodirwan Region in Iran. International Journal of Advanced Science and Technology, vol. 68.

Bielecka E. (2015). Geographical data sets fitness of use evaluation. Geodetski Vestnik Vol. 59 (2015), No. 2, 335-348. DOI: 10.15292/geodetskivestnik.2015.02.335-348.

Bober A., Calka B., \& Bielecka E. (2016). Application of state survey and mapping resources for selecting sites suitable for solar farms. Proceedings of the $16^{\text {th }}$ International Multidisciplinary Scientific GeoConferences SGEM, ISBN 978-6197105-58-2 / ISSN 1314-2704, June 28 - July 6, 2016, Book2 Vol. 1, 593-600 pp. DOI: 10.5593/SGEM2016/B21/S08.074.

Brzezinska-Klusek M., Moscicka A., \& Debowska A. (2013). OGNIWO - Tool for Integration Different Spatial Data Resources. 13th SGEM GeoConference on Informatics, Geoinformatics And Remote Sensing, SGEM2013 Conference 
Proceedings, ISBN 978-954-91818-9-0 / ISSN 1314-2704, June 16-22, 2013, Vol. 1, pp. 481-488. DOI:10.5593/SGEM2013/BB2.V1/S08.024.

Calka B., Bielecka E., \& Zdunkiewicz K. (2016). Redistribution population data across a regular spatial grid according to buildings characteristics. Geodesy and Cartography. Volume 65, Issue 2, Pages 149-162. DOI: https://doi.org/10.1515/geocart-2016-0011.

Directive of the European Parliament and of the Council 2009/28/EC of 23 April 2009.

Directive of the European Parliament and of the Council 2010/75/EU of 24 November 2010 on industrial emissions (integrated pollution prevention and control).

Effat H. A. (2013). Selection of Potential Sites for Solar Energy Farms in Ismailia Governorate, Egypt using SRTM and Multicriteria Analysis. International Journal of Advanced Remote Sensing and GIS, Vol. 2.

Gąsiorowski J., \& Bielecka E. (2014). Land fragmentation analysis using morphometric parameters. Proceedings of the $9^{\text {th }}$ International Conference Environmental Engineering, elSBN 978-609-457-640-9 / eISSN 2029-7092DOI: 10.3846/enviro.2014.205.

Hejmanowska B., \& Hnat E. (2009). Wielokryterialna analiza lokalizacji zabudowy na przykładzie gminy Podegrodzie (Multi-factoral evaluation of residential area locations: case study of Podegrodzie local authority). Archives of Photogrammetry, Cartography and Remote Sensing, Vol.20, pp.109-129.

Hott R., Santini R., \& Brownson J. (2012). GIS-based Spatial Analysis For LargeScale Solar Power And Transmission Line Issues: Case Study of Wyoming, U.S., Proceedings of the 41st American Solar Energy Society Meeting.

Janke J. R. (2010). Multicriteria GIS modeling of wind and solar farms in Colorado. Renewable Energy 35, pp. 2228-2234.

Ławniczak R., \& Kubiak J. (2016). Geometric accuracy of topographical objects at Polish topographic maps, Geodesy and Cartography. Volume 65: 55-66, DOI: 10.1515/geocart-2016-0003.

Lorek D. (2016). Multimedia integration of cartographic source materials for researching and presenting phenomena from economic history, Geodesy and Cartography. Volume 65: 271-282, DOI: 10.1515/geocart-2016-0015.

Malczewski J. (2006). GIS-based multicriteria decision analysis: a survey of the literature. International Journal of Geographical Information Science, Vol. 20, No. 7, pp. 703-726.

Malczewski J. (2004). GIS-Based Land-Use Suitability Analysis: A Critical Overview. Progress in Planning , Vol. 62, No. 1, pp. 3-65.

Maleta M., \& Calka B., Examining spatial autocorrelation of real estate features using Moran statistics, SGEM2015 Conference Proceedings, ISBN 978-619-7105-35-3 / ISSN 1314-2704, June 18-24, 2015, Book2 Vol. 2, pp. 841-848 pp, DOI: 10.5593/SGEM2015/B22/S11.106.

McKinney M. (2014). Site Suitability Analysis for a Solar Farm in Watauga County, NC. Journal of Student Research in Environmental Science at Appalachian, Vol. 4.

Medyńska-Gulij B. (2014). Cartographic sign as a core of multimedia map prepared by non-cartographers in free map services, Geodesy and Cartography. Volume 63:55-64, DOI: 10.2478/geocart-2014-0004.

Merrouni A., Ab. Mezrhab, \& Mezrhab A. (2013). CSP sites suitability analysis in the Eastern region of Morocco. Energy Procedia, Vol. 49. 
Ostaszewska K., \& Richling A. (2009). Geografia fizyczna Polski (Geography of Poland). Warszawa: Wydawnictwo Naukowe PWN.

Paska J., \& Surma T. (2014). Electricity generation from renewable energy sources in Poland. Renewable Energy 71, pp. 286-294.

Pokonieczny K. (2016). Using artificial neural networks to determine the location of wind farms. Miedzna district case study. Journal of Water and Land Development. No. 30 p. 101-111. DOI: 10.1515/jwld-2016-0026.

Regulation of the Minister of Energy of 1 December 2016 on calculation of the amount of state aid for producers of electricity from a renewable energy source, generated in a renewable energy installation.

Saaty R.W. (1987). The Analytic Hierarchy Process - what it is and how it is used. MATHI Modelling, Vol. 9.

Serrano-Luján L., Espinosa N., Abad J., \& Urbina A. (2017). The greenest decision on photovoltaic system allocation.

Strzelecki Z. (2011). Plan Zagospodarowania Przestrzennego Województwa Mazowieckiego, Warszawa (Ecophysiographic description of the area development plan of the Mazovian Voievodeship).

Tahri M., Hakdaoui M., \& Maanan M. (2015). The evaluation of solar farm locations applying Geographic Information System and Multi-criteria Decision-Making methods: Case study in southern Morocco. Renewable and Sustainable Energy Reviews. Pp. 1354-1362.

Tomala J., Kuźma M., \& Mościcka A. (2016). Application of excluded areas in travel time mapping. Proceedings of the $16^{\text {th }}$ International Multidisciplinary Scientific GeoConferences SGEM, Book 2: informatics, Geoinformatics and Remote Sensing, Vol. III, Albena (Bulgaria), June 28 - July 6, pp. 63-70, DOI: 10.5593/SGEM2016/B23/S11.009.

Ustawa z dnia 7 lipca 1994 r. - Prawo budowlane, Dz.U. 1994 nr 89 poz. 414. (The act of 7 July 1994 on building law).

Ustawa z dnia 27 marca 2003 r. - Ustawa o planowaniu i zagospodarowaniu przestrzennym, Dz. U. 2003 nr 80 poz. 717 (The act of 23 March 2003 on planning and spatial development).

\section{Authors:}

Michal Mierzwiak1), michal.mierzwiak@wat.edu.pl

Beata Calka 1), beata.calka@wat.edu.pl

1) Military University of Technology in Warsaw

Faculty of Civil Engineering and Geodesy,

Kaliskiego St. 2, 00-908, Warsaw, Poland 